\title{
The Relationship Between CSR Disclosure and Company Profitability in Indonesia
}

\author{
Seto Satriyo Bayu Aji ${ }^{1, *}$ Ondrej Castek ${ }^{2}$ \\ 1,2 Masaryk University, Brno, Czech Republic \\ *Corresponding author. Email:491280@muni.cz
}

\begin{abstract}
In this modern era, companies could depend on CSR activities to increase public trust in company products, resulting in rising company profits. This paper focuses on the relationship between CSR Disclosure and Company's Profitability in the Asia Sustainability Report Awards (ASRA) 2019 Winner Company. This quantitative research is conducted to prove the effect of CSR disclosure on Profitability (Return on Asset (ROA), Return on Equity (ROE), and Net Profit Margin (NPM) ratio) as the measurement tools. This research uses secondary data from the 24 ASRA winner companies' financial reports in the 2017-2019 periods. The findings indicate that Corporate Social Responsibility Disclosure positively affects ROA and NPM. In reverse, it has a negative effect on ROE.
\end{abstract}

Keywords: Corporate social responsibility, return on asset, return on equity, net profit margin.

\section{INTRODUCTION}

Nowadays, the concept of CSR is very dynamic. In this present day, companies rely on CSR activities to obtain public trust in company products, which might increase company profits. However, this point is still a debate among society. This condition is essentially the same as expressed by [1] that stated:

"Social responsibility is a difficulty experienced by almost all companies in the private competitive world. It would encourage certain parties to take responsibility for their actions and leaves them less likely to manipulate others for selfish purposes. People can do their best but only at their own cost".

Nowadays, the company must be responsible to society. Many business activities pretend to do benevolence as they consider it as part of their social responsibility.

The company could not just anticipate the business process to obtain profit; it requires some strategies to gain higher profit; this statement was supported by [2], which claimed that CSR is dynamic and modest planning for companies. The business entities shall develop a range of initiatives to counter this convergence of societal interests, the environment, and associated business norms regarding how broadly and how appropriately social responsibility frameworks can be integrated into global policies and day-to-day activities. [3]. In essence, CSR's concept has expanded from being an altruistic approach to a strategic work necessity for firms to achieve a competitive improvement [4].
CSR activity could be one of the company's best strategies. Could CSR activity disclosure lead the company to increase its profitability? The business process's primary purposes are to get higher profits and maintain its sustainability by following the going concern principle.

This research analyses the relationship between CSR disclosure and its profitability, which earned the Asia Sustainability Report Awards in 2019. The lack of empirical evidence concerning the increase in profits in companies that receive awards for their CSR disclosure makes this issue interesting to study. This study intends to know whether by disclosing CSR, a company could create a competitive advantage and maintain the company's sustainability compared to its competitors. Furthermore, since there are still many debates regarding CSR activities' effect on the company's profitability; this research also aims to confirm its CSR disclosure effect on profitability. It is hoped this research will be an additional reference regarding CSR disclosure on company profits. Based on the statement above, this research question is: "Does CSR Disclosure have a relationship with the company's profitability?". This research applies three profitability ratios as a measurement. There are ROA, ROE, and NPM.

\section{LITERATURE REVIEW}

Corporate Social Disclosure (CSD) may be outlined in annual reports of companies or separate social reports as a financial and non-financial source of providing of a company's relationship with its 
physical and socio-cultural context. [5]. In the future, the corporation will strive to maintain a definite mutual relationship between Corporate Social Responsibility and its business outcomes. [6] The disclosure and reporting of corporate social responsibility are projected to become highly important, as the accounting area is expanded to cover several products not currently disclosed. [7]. Commonly, companies demand to generate CSR in order to gain more profit in the following year. Therefore, a CSR disclosure report could be a competitive advantage to increasing its value and a better understanding between the company and society; we could measure firm value from its profitability [8]. According to [9], we found that there are some ratios we could use as a standard of the company's annual report :

\section{a. Net Profit Margin}

This ratio provides for measuring the net profits earned from each sale and allows for the company's activities' performance.

\section{b. Return on Asset}

Return on assets is used to determine the business entities' capability to use assets to earn a profit. It compares earnings with those assets that could achieve profits.

c. Return on Equity

This ratio is used to quantify the return, including both preferred and common stockholders.

We use ROA, ROE, and NPM since these are the business's most common profitability ratios in the annual report to present profitability. This study uses ROA to show that the company controls its costs and utilizes its resources; it is suitable for the CSR since the company usually use their Asset to hold and support their CSR activities. At the same time, NPM is applied as it will present how its management could generate enough sales profit. It could examine as well, whether operating costs and overhead costs are being contained. It is suitable for this study to find out how CSR activities will increase profit.

Previous studies confirmed that CSR could affect the company's profitability. [10] found that when the company involves in social and environmental action through its CSR, it will impact earnings, although it often takes some time for the company to gain profits as desired. [11] Their research has shown a positive and significant association between CSR Disclosure with ROA and NPM as ratio profitability indicators in the cement industry. This study is also supported by another research written by [12], which stated that CSR had a positively significant effect on profitability by applying the NPM ratio; meanwhile, it negatively influenced ROA and ROE. Another study completed by [13] stated that CSR negatively affects ROA and ROE. Based on the previous explanation, we could notice the mixed results of CSR's effect on profitability. Therefore, it could be a constructive research gap for this study, and these are the hypotheses in this study:

Hypothesis 1: CSRD has a positive effect on ROA Hypothesis 2: CSRD has a positive effect on ROE Hypothesis 3: CSRD has a positive effect on NPM

\section{METHODS}

The data is collected from the ASRA 2019 Winner's companies' financial report in 2017-2019. A quantitative method is applied to prove the effect of CSRD toward profitability. Regression analysis is used as a testing tool.

CSRD measurement is based on a Corporate Social Responsibility Disclosure Index (CSRDI) proxies that consist of seven disclosure focuses: Environment, Energy, Health and Safety at Work, Others with Labor, Products, Community Chat, and General that developed by [14]. Profitability is the ability of the company to generate a profit for a reasonable length of time. In this study, ROA, ROE, and NPM are used as profitability ratios.

CSR Disclosure Index is a reference used to evaluate the significance of the numbers of CSR programs disclosed by an entity in the annual report. According to [14], the CSR Disclosure index consists of seven disclosures, precisely Environmental Issues, Energy, Worker's Health, Worker's Safety, Labor Issues, Company's Products, Company's Involvement in Society, and General Issues. Content analysis methods shall measure the level of social responsibility contained in the annual report.

This research provides the Indexing "yes / no approach." In this technique, the researcher will give the number "1" (one) if a company fill or disclose the social disclosure category. On the contrary, the researcher will give the number "0" (zero) if there are undisclosed criteria by the company. The formula used in calculating the CSR Disclosure Index is as below:

\section{CSRDI $=\left(\sum X \mathbf{X j}\right) / \mathbf{n j} X 100 \%$}

Where :

CSRDI: CSR Disclosure Index in company $\mathrm{j}$

nj: Number of CSR disclosure criteria in company $j$, $\mathrm{nj} \leq 78$

Xij: Value $1=$ if criteria $\mathrm{i}$ is disclosed in the annual report; $0=$ if criterion $i$ was not disclosed in the annual report

ROA is the first ratio used to assess the profitability of the company in this research. ROA represents the ability of the entity to earn a profit from the utilization of its assets. ROA measures the 
percentage of net income of the total assets of the company. ROA shows how efficient the company is in using its assets for the company's operational activities. According to [9], ROA could be measured:

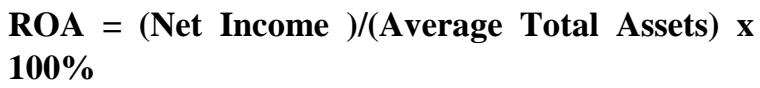
$100 \%$

Various empirical studies were testing the relationship between CSR and ROE. In this research, we implement the accounting measurement used by [15]; as shown below :

\section{ROE $=($ Net Income $/$ Total Equity $) \times 100 \%$}

Furthermore, the NPM is used as a ratio to assess the profitability of the company. NPM is a profitability measure that reflects the company's capability to obtain profits from its operational activities. Concerning the CSR Disclosure, NPM reveals the influence of CSR disclosures made by the company on the profits or profits obtained in one period. This ratio is a comparison between net income after tax with the sales. According to [9], NPM could be assessed:

\section{NPM $=($ Net Income $) /($ Net Sales $) \times 100 \%$}

This study uses the Partial Least Square (PLS) approach with SmartPLS 3.0 as the data analysis. PLS is an alternative method that shifts the covariance-based to a variant-based SEM. [16]. To perform parameter estimation, we examine convergent validity (Outer Model). We use the RSquare and T-Statistic Test for assessing the Inner Model.

\subsection{Measurement Evaluation (Outer Model)}

We applied convergent validity as the examining tool for the validity test. We used convergent validity as a measuring tool for assessing the similarity between the part score and the construct score, with deliberate measures evaluated. If the value has more than 0,5 (significance of 0,05 and obtains $\mathrm{T}$ statistic more than 1,64), the individual reflective assessment is high.

\subsection{Assessing Inner Model or Research Results}

The next section is to evaluate the structural model (inner model). The $\mathrm{r}^{2}$ ( $\mathrm{R}$ Square) test is the explanatory power of the model obtained by measuring the coefficient of determination $\left(\mathrm{r}^{2}\right)$ [17].

\subsection{Hypothesis Testing}

The findings of the study are interpreted and discussed in this section with explanations. The hypotheses' analysis is completed by examining the tvalue and hence the direction coefficient $(\beta)$. The evaluation of the hypothesis clarifies the path of the relationship between variables used in this study. This test conducts a path analysis of the model that was developed. A hypothesis test is to observe the tstatistic significance and likelihood value.

We use alpha 5\% and the t-statistic value 1.96 to examine the hypothesis. The criterion for accepting the hypothesis is when the t-statistic $>1.96$, a hypothesis is acceptable if it has a p-value $<0.05$.

\section{RESULT}

The selection of the sample in this research was defined by applying a purposive sampling method with several provisions. The criteria for selecting the sample for this research: 1). The companies published complete annual financial reports for the observation period of 2017-2019. 2) The company announced its social responsibility activities consecutively during the observation period of 2017 - 2019. From these criteria, we get 24 companies suitable for this research.

Table 1. Research Sample

\begin{tabular}{|l|r|}
\hline \multicolumn{1}{|c|}{ Criteria } & \multicolumn{1}{|c|}{ Total } \\
\hline Asia Sustainability Report Awards 2019 & \\
Winner List & 41 \\
\hline \begin{tabular}{l|r} 
Not yet published a complete report in 2017- \\
2019 period
\end{tabular} & 17 \\
\hline Total Sample & 24 \\
\hline
\end{tabular}

Source: Data processed 2020

Descriptive statistical analysis was implemented to provide an overview of the variables applied in the study. The following table illustrates the Standard Deviation, mean, maximum, and minimum value. Table 2 below describes the statistic descriptive from this research :

Table 2. Statistics Descriptive

\begin{tabular}{|l|c|c|c|c|c|}
\hline Variable & N & \multicolumn{1}{|c|}{ Min } & Max & Mean & \multicolumn{1}{c|}{$\begin{array}{c}\text { Std. } \\
\text { Dev }\end{array}$} \\
\hline CSRD & 72 & 64,103 & 78,205 & 72,543 & 3,631 \\
\hline ROA & 72 & 0,010 & 28,100 & 4,815 & 5,444 \\
\hline ROE & 72 & 0,100 & 84,800 & 14,356 & 14,958 \\
\hline NPM & 72 & 0,300 & 41,789 & 10,970 & 10,044 \\
\hline
\end{tabular}

Source: data processed by SmartPLS 3.0 2020 
The descriptive statistical test above shows that the average value of the CSRD variable is $72.5427 \%$, with a standard deviation value of 3.6310 , which means that the data variation is relatively small. The lowest value of the CSRD variable is $64,1026 \%$ PT Kideco Jaya Agung (KIDECO) in 2017, up to the highest value of $78,2051 \%$; PT ANTAM, Tbk and PT Indo Tambangraya Megah, Tbk in 2019.

\subsection{Evaluation of Outer Model}

Evaluation of Outer Model Discriminant validity shall be implemented to ensure that a specific latent variable concept is distinct from another variable. The model has robust discriminant validity if each loading value within each latent variable indicator has the most significant loading value for other loading values relative to other latent variables. The findings of the discriminant validity assessments were provided in Table 3 below :

Table 3. Discriminant validity

\begin{tabular}{|l|r|r|r|r|}
\hline & CSRD & ROA & ROE & NPM \\
\hline CSRD & 1 & 0,166 & 0,832 & 0,534 \\
\hline ROA & 0,166 & 1 & 0,331 & 0,376 \\
\hline ROE & 0,832 & 0,331 & 1 & 0,487 \\
\hline NPM & 0,534 & 0,376 & 0,487 & 1 \\
\hline
\end{tabular}

Source: data processed by SmartPLS 3.0 2020

The table above presents that each indicator's latent construct loading value shows better than other constructs' loading value. It means that all indicators meet discriminant validity.

\subsection{Evaluation of Inner Model ( $r^{2}$ test)}

The $r^{2}$ measure is the interpretive value of the exemplary that was measured by evaluating the coefficient of determination $r^{2}$ [17], as explained in Table 4. below :

Table 4. $r^{2}$ Test

\begin{tabular}{|l|l|}
\hline Dependent Variable & \multicolumn{1}{|c|}{$\boldsymbol{r}^{2}$ value } \\
\hline ROA & 0,143 \\
\hline ROE & 0,234 \\
\hline NPM & 0,182 \\
\hline
\end{tabular}

Source: data processed by SmartPLS 3.0 2020

As Table IV shown above, the ROA value is 0,143 , indicating that the CSRD could explain ROA $14,3 \%$ variance. R-Square value also shows that ROE value is 0,243 , which means that CSRD could explicate ROE $24,3 \%$. It is also found in Table V that the NPM value is 0,182 ; it is indicating that CSR could show NPM 18,2\%.

\subsection{Hypothesis Testing Result}

The evaluation of the hypotheses is carried out by examining the t-value and path coefficient $(\beta)$. As seen in Table 5, two hypotheses are supported, and one hypothesis is not supported.

Table 5. Hypothesis Testing

\begin{tabular}{|l|l|c|c|l|}
\hline Hypothesis & Relationship & $\begin{array}{c}\text { B } \\
\text { value }\end{array}$ & $\begin{array}{c}\text { T- } \\
\text { value }\end{array}$ & Result \\
\hline $\begin{array}{l}\text { Hypothesis } \\
1\end{array}$ & $\begin{array}{l}\text { CSRD- } \\
\text { >ROA }\end{array}$ & 0,155 & 2,215 & Supported \\
\hline $\begin{array}{l}\text { Hypothesis } \\
2\end{array}$ & $\begin{array}{l}\text { CSRD- } \\
\text { >ROE }\end{array}$ & $-0,034$ & 0,012 & $\begin{array}{l}\text { Not } \\
\text { Supported }\end{array}$ \\
\hline $\begin{array}{l}\text { Hypothesis } \\
3\end{array}$ & $\begin{array}{l}\text { CSRD- } \\
\text { >NPM }\end{array}$ & 0,231 & 3,514 & Supported \\
\hline
\end{tabular}

Source: data processed by SmartPLS 3.0 2020

The data analysis shows that the CRSD has positively affected ROA and NPM. On the contrary, we also found that CSRD has negatively affect ROE. This research supports the one written by [11] [12], and it is following [10], who claimed that CSR could affect the financial performance of the company.

CSRD variable has a positive relationship with company profitability, proxied by ROA and NPM. Nonetheless, in the NPM proxy, the Corporate Social Responsibility (CSR) variable significantly influences company profitability. We could conclud that the higher the disclosure of CSR in a company, it will obtain higher profit from the company's sales since the consumers will prefer commodities produced by companies that perform their social responsibility, as creates a positive image in society.

From the data, we conclude that CSR has no significant effect on ROE. It could happen since companies that implement CSR have weaknesses in terms of costs. Many companies consider the costs incurred to provide social responsibility reports as insignificant. The company presumes this cost will reduce the company's net profit, and obviously, it will also affect shareholder profits and company wealth. It supports the research result by [18].

\section{CONCLUSION}

We find that CSRD positively affects the company's profitability by measuring the ROA and NPM ratio on ASRA 2019 winner companies. It is also noticed an exciting finding that CSRD has a negative effect on ROE. Thus, we might conclude that the higher the company's CSR disclosure would increase its profitability.

The CSR disclosure could significantly improve the image of the company in the future. It would attract people to buy the company's product and also attract an investor. CSR would be a necessity for businesses to exist in society and to thrive on the 
market. The results derived are expected to be the answers to the research questions in this study.

We may conclude that if a company receives an award for its CSR disclosure quality, it will indirectly affect its profitability. In other words, with CSR disclosure, the company will get a positive image from the public, and it will escalate buying interest in its products, which will indirectly impact company profitability. With these findings, it is expected that other companies will compete to reveal the CSR activities that have been conducted so that it will be a competitive advantage to increase company profits in the future.

We conclude that CSR's progress is heading to the right form and would be a natural part of the business practice. Society would value the quality of the company from its CSR activities. They would be more appreciate the companies that contribute generously to the environment

\section{AUTHORS' CONTRIBUTION}

Author 1 developed the theoretical formalism and performed the data analysis. Both authors contributed to the final version of the manuscript. Author 2 helps supervised the project.

\section{ACKNOWLEDGMENTS}

This research is supported by Masaryk University Specific Research Grant with contract number MUNI/A/1092/2019.

\section{REFERENCES}

[1] M. Friedman, The Social Responsibility of Business Is to Increase Its Profits, The New York Times Magazine, (13 September), 1970, pp $32-33,122,124,126$.

[2] D.B. Chandler, W.B. Werther, Strategic CSR: Stakeholders, globalization, and sustainable value creation, Thousand Oaks, CA: Sage Publications, 2013.

[3] Y.A. Babalola, The impact of corporate social responsibility on firms' profitability in Nigeria, European Journal of Economics, Finance and Administrative Sciences, 45(45), 2012, pp 3950 .

[4] K.F. Latif, A. Sajjad, Measuring corporate social responsibility: A critical review of survey instruments, Corporate Social Responsibility and Environmental Management Journal, vol.8, issue. 6, Wiley, 2018, pp. 1174-1197, DOI: https://doi.org/10.1002/csr.1630
[5] J. Guthrie, M.R. Mathews, Corporate social accounting in Australasia, Research in Corporate Social Performance and Policy, vol. 7, 1985, pp. 251-277.

[6] B. Ven Van De, J. Graafland, The strategic and moral motivation for corporate social responsibility Strategic and Moral Motivation for Corporate Social Responsibility, Journal of Corporate Citizenship, 22(20278), 2006, pp.111-123.

[7] N. Abu-baker, K. Naser, Empirical Evidence on Corporate Social Disclosure (CSD) Practices in Jordan, International Journal of Commerce and Management, 10 (3), 2000, pp.18-34, DOI: https://doi.org/10.1108/eb047406

[8] M.S. Hermawan, S.G. Mulyawan, Profitability And Corporate Social Responsibility: An Analysis Of Indonesia's Listed Company, Asia Pacific Journal of Accounting and Finance, vol. 3(1), 2014, pp. 15-31.

[9] C.H. Gibson, Financial Reporting Analysis: Using Financial Accounting Information, vol.12e, South-Western, Cengage, Learning, 2011.

[10] L.M. Emilsson, M. Classon, K. Bredmar, CSR and the quest for profitability - using Economic Value Added to trace profitability, International Journal of Economics and Management Sciences, vol. 2(3), 2012, pp. 43-54.

[11] M.Almar, R.Rachmawati, A.Murni, Responsibility (CSR) Terhadap Profitabilitas Perusahaan, Seminar Nasional Akuntansi \& Bisnis, 2012, pp.514-526, DOI: https://doi.org/10.30871/jaemb.v5i2.353

[12] R. Heyanto, A. Juliarto, Pengaruh Corporate Social Responsibilityterhadap Profitabilitas Perusahaan (Studi Empiris pada Perusahaan Manufaktur yang Terdaftar di Bursa Efek Indonesia Periode 2014- 2015), Diponegoro Journal Of Accounting, vol. 6 (4), 2017, pp. 1-8.

[13] M. Rehan, M.I. Khan, M.K. Khan, Effect of Corporate Social Responsibility on Profitability of Banks, European Academic Research, vol. 6(7), 2018, pp. 3763-3782.

[14] E. Sembiring, Karakteristik Perusahaan Dan Pengungkapan Tanggung Jawab Sosial: Study Empiris Pada Perusahaan Yang Tercatat Di Bursa Efek Jakarta., Simposium Nasional Akuntansi XVI, 2005, pp. 379-295.

[15] H. Dkhili, H. Ansi, The Link between Corporate Social Responsibility and Financial 
Performance: The Case of the Tunisian Companies, Journal of Organizational Knowledge Management, IBIMA Publishing, vol.2012(2012), 2012, pp.1-11, DOI: https://doi.org/10.5171/2012.640106

[16] Ghozali, Structural Equation Modeling Metode Alternatif Dengan Partial Least Square, Semarang, Badan Penerbit Universitas Diponegoro, 2008.

[17] P.I. Santos, K.K, Wei, H.C. Chan, User involvement and user satisfaction with information-seeking activity, European Journal of Information Systems, vol. 14(4), 2005, pp. 361-370.

[18] A.S. Putra, Pengaruh Corporate Social Responsibility Terhadap Profitabilitas Perusahaan (Studi Empiris pada Perusahaan Sektor Industri Barang Konsumsi yang Terdaftar di Bursa Efek Indonesia Tahun 20102013), Jurnal Nominal, vol. 4(12), 2015, pp. 88110. 